\title{
Splenic B cell lymphoma with circulating villous lymphocytes: differential diagnosis of $B$ cell leukaemias with large spleens
}

\author{
J V MELO,* U HEGDE, $\dagger$ A PARREIRA,* I THOMPSON, $\ddagger$ I A LAMPERT, \\ D CATOVSKY*
}

From the *Medical Research Council Leukaemia Unit, Royal Postgraduate Medical School, London, the $\dagger$ Department of Haematology, Ealing Hospital, and the $\ddagger$ Department of Histopathology, Hammersmith Hospital, London

SUMMARY The clinical, haematological, morphological and histological features of a series of 22 patients presenting with splenic lymphoma with circulating villous lymphocytes were assessed and compared with those of patients with other forms of chronic B cell leukaemia in an attempt to differentiate this condition from hairy cell leukaemia, prolymphocytic leukaemia, and chronic lymphocytic leukaemia, with which this condition has many features in common. The disease was twice as common in men than in women, with a mean (SD) age at diagnosis of 72 (9) years, and the most consistent presenting feature was massive enlargement of the spleen, which showed white and red pulp disease with a plasmacytic component. Small monoclonal bands were found in $60 \%$ of cases.

The development of new methods for identifying specific markers for different lymphocyte populations has shown that much of the clinical variability among lymphoid leukaemias can be explained by the fact that they are different diseases. Among the neoplastic diseases of B lymphocytes at an intermediate late stage of maturation, chronic lymphocytic leukaemia (CLL), prolymphocytic leukaemia (PLL), and hairy cell leukaemia (HCL) have been the most well defined. In clinical practice, however, a number of cases with malignant proliferations of mature B cells seem to share some features of these diseases, but cannot be confidently assigned to any of them. These comprise mainly non-Hodgkin's lymphomas in leukaemic phase, a heterogeneous group of disorders which has only begun to be accurately defined.

Among these disorders, a characteristic type of diffuse lymphoma with circulating lymphocytes that resemble hairy cells deserves special attention in its differential diagnosis from HCL, PLL, and CLL. This lymphoma has been described under a variety of names by other workers, ${ }^{1-4}$ and has recently been reviewed by Spriano et al. ${ }^{5}$ It is characterised by splenic enlargement, a high incidence of monoclonal

Accepted for publication 3 February 1987 serum paraprotein concentration, and infiltration of the peripheral blood by atypical lymphoid cells with irregular cytoplasmic outlines. Little has been published on the detailed immunological phenotype of these lymphocytes as most studies have emphasised the importance of careful histological examination of the spleen in distinguishing this lymphoma from HCL.

We report the clinical, haematological, morphological, immunological and histological features of 22 patients presenting with splenic lymphoma with circulating villous lymphocytes (SLVL) and compare these features with those of patients with other forms of chronic B cell leukaemia, in an attempt to define the wide ranging symptoms of each disease more accurately.

\section{Material and methods}

We studied 22 patients with SLVL. The selection of these cases was based on the finding of at least $30 \%$ atypical lymphocytes with cytoplasmic villi in the peripheral blood, which could not be classified as hairy cells from typical HCL or from HCL variant. ${ }^{6}$ Most of these cases had been referred to us with a presumptive diagnosis of HCL $(44 \%)$, CLL $(30 \%)$, or PLL $(9 \%)$; in four cases $(17 \%)$ the possibility of an atypical non-Hodgkin's lymphoma in leukaemic 
phase was raised by the referring physician. The clinical and laboratory findings in these patients were compared with those of separate groups of patients with HCL (41 cases), HCL variant (five cases), PLL (40 cases) and CLL (174 cases).

Features chosen for detailed analysis comprised: sex, age, size of palpable spleen and liver, obvious lymph node enlargement, haemoglobin concentration, white cell count, platelet count, presence of monoclonal gammopathy and histological features of the spleen.

Cell morphology was studied by light microscopy in peripheral blood and bone marrow films stained with May-Grünwald-Giemsa. Demonstration of acid phosphatase and tartrate resistant acid phosphatase on cytocentrifuged cells was done in accordance with the International Committee for Standardisation in Hematology recommendations. ${ }^{7}$ Leucocyte volume distributions were measured by a Coulter model ZBI counter linked to a Coulter channeliser (Coulter Electronics, Luton, England). ${ }^{8}$

Immunophenotyping was carried out in splenic mononuclear cell suspensions obtained by density gradient separation in Lymphoprep (Nyegaard, Oslo, Norway) or peripheral blood, or both. The following markers were investigated: (i) formation of rosettes with sheep erythrocytes (E rosettes) and with mouse erythrocytes ( $M$ rosettes); (ii) expression of surface membrane immunoglobulin (SmIg), cytoplasmic immunoglobulin (CyIg), and other lymphocyte differentiation antigens as detected by monoclonal antibodies using indirect immunofluorescence, or indirect immunoperoxidase staining, or both.

The monoclonal antibodies used were: mouse antihuman $\operatorname{Ig} \mu, \delta, \alpha, \gamma, \kappa$ and $\lambda$ chains (gift from $\operatorname{Dr} \mathrm{N}$ Ling, University of Birmingham); GRB1 (gift from Professor F Garrido, Granada, Spain), anti-class II MHC antigens; anti-B1 [CD20], anti-B2 [CD21] and J5 [CD10] (Coulter, Hialeah, Florida); FMC7 (Sera Lab, Crawley Down, England), which specifically recognises a subpopulation of normal peripheral blood B lymphocytes and most cells in B-PLL and HCL; anti-HC2 (gift from Dr D Posnett, Rockefeller University of New York, USA), anti-hairy cell ${ }^{9}$; anti-Tac (CD25) (gift from Dr T Uchiyama, University of Kyoto, Japan); UCHT2 [CD 5] (Seward Laboratories, Bedford, England); OKT10 (Orthoclone, High Wycombe, England) against plasma cells and activated B and T cells; RFB1 (gift from Dr M Bodger, Christchurch Hospital, New Zealand), which reacts with stem cells, CLL, and HCL cells ${ }^{10}$; and BU 11 (gift from Dr $\mathrm{N}$ Ling, University of Birmingham, England), reactive with B lymphocytes at the terminal stage of maturation. ${ }^{11}$

The second layer reagent for immunofluorescence tests consisted of a fluorescein isothiocyanate conju- gated $\mathrm{F}(\mathrm{ab})_{2}$ fragment of goat antimouse IgG or IgM (Dynatech Laboratories Ltd, Billingshurst, England). For immunoperoxidase staining, the second and third layer reagents were peroxidase conjugated rabbit antimouse Ig and peroxidase conjugated swine antirabbit Ig (both from Dakko, High Wycombe, England), respectively. The tests for CyIg (immunofluorescence method), as well as those for cytoplasmic expression of other differentiation antigens by immunoperoxidase staining were done on cytocentrifuged preparations. Results of the immunofluorescence tests were read on a Zeiss 14 fluorescence microscope (Zeiss, Oberkochen, West Germany), and the intensity of fluorescence in cell suspensions was also assessed by readings on a FACS Analyzer (Becton Dickinson, Sunnyvale, California, USA).

\section{Results}

CLINICAL AND HAEMATOLOGICAL FEATURES

The 22 patients in this series comprised 14 men and eight women, whose clinical and haematological features are summarised in table 1 . The mean age at diagnosis was 72 years (range 57-88 years).

Presenting symptoms were usually limited to mild weakness, fatigue, and abdominal discomfort caused by the enlarged spleen. In five cases the lymphoproliferative disorder was an incidental finding during the investigation of unrelated problems (rheumatoid arthritis in three patients, psoriatic arthritis in one, and melanoma in the fifth). The physical sign most often seen was massive enlargement of the spleen. It was palpable in 18 of the 22 patients, and extended from 7 to $27 \mathrm{~cm}$ below the costal margin in 15 . The liver was palpable between 2 and $10 \mathrm{~cm}$ below the costal margin in nine patients. Lymph nodes were enlarged (2.0 to $2.5 \mathrm{~cm}$ in diameter) in more than one place in five patients, but in only one was this generalised.

The haemoglobin concentrations ranged from $6 \cdot 2$ to $15.4 \mathrm{~g} / \mathrm{dl}$, and were below $12 \mathrm{~g} / \mathrm{dl}$ in 10 of the 21 cases. In 12 patients the platelet count was below 150 $\times 10^{9} / 1$; the lowest counts $\left(60-70 \times 10^{9} / 1\right)$ were recorded in the two patients who had the most severe anaemia. The white cell count ranged from 3 to $38 \times$ $10^{9} / 1$; in only three patients was it below $10 \times 10^{9} / 1$. Lymphoid cells comprised 51 to $98 \%$ of the total leucocyte count; in absolute numbers the lymphoid cells ranged from $1.8 \times 10^{9} / 1$ to $35 \times 10^{9} / 1$.

Monoclonal gammopathy ( $\mathrm{M}$ band) was found in nine of the 15 patients in whom immunoelectrophoresis was performed. In six of these the $\mathrm{M}$ band was present only in the serum (IgM in four and IgG in two); in two patients it was found only in the urine as free light chains, and in one case both 
Table 1 Clinical and haematological features in 22 cases of splenic lymphoma with villous lymphocytes

\begin{tabular}{|c|c|c|c|c|c|}
\hline \multirow[b]{2}{*}{ Case No } & \multirow[b]{2}{*}{ Sex/age } & Spleen & Liver & \multirow{2}{*}{$\begin{array}{l}\text { Lymph node } \\
\text { enlargement }\end{array}$} & \multirow[b]{2}{*}{ Haemoglobin $(\mathrm{g} / \mathrm{dl})$} \\
\hline & & \multicolumn{2}{|c|}{ (cm below costal margin) } & & \\
\hline 1 & M, 75 & 10 & 0 & 0 & 12 \\
\hline 2 & $\mathrm{M}, 88$ & 0 & 0 & 0 & 13 \\
\hline 3 & $M, 62$ & 27 & 0 & Generalised & 7 \\
\hline 4 & M, 78 & 3 & 4 & 0 & 13 \\
\hline 5 & M, 75 & 23 & 8 & Moderate & 12 \\
\hline 6 & M, 59 & 12 & 0 & 0 & 15 \\
\hline 7 & $M, 63$ & 16 & Not recorded & 0 & 11 \\
\hline 8 & $\mathrm{~F}, 77$ & 15 & 10 & 0 & Not recorded \\
\hline 9 & M, 74 & 3 & 2 & 0 & 14 \\
\hline 10 & $\mathrm{~F}, 81$ & 18 & 10 & 0 & 11 \\
\hline 11 & F, 76 & 15 & 2 & 0 & 12 \\
\hline 12 & F, 84 & 15 & Not recorded & Not recorded & 10 \\
\hline 13 & M, 57 & 12 & 0 & 0 & 10 \\
\hline 14 & F, 58 & 7 & 5 & 0 & 11 \\
\hline 15 & $M, 60$ & 15 & Not recorded & 0 & 12 \\
\hline 16 & F, 74 & 15 & 5 & Moderate & 11 \\
\hline 17 & $\mathrm{~F}, 78$ & 16 & 2 & Moderate & 7 \\
\hline 18 & $\mathrm{M}, 83$ & 0 & 0 & 0 & 9 \\
\hline 19 & M, 71 & 10 & 0 & Moderate & 12 \\
\hline 20 & $M, 62$ & 0 & 0 & 0 & 12 \\
\hline 21 & M, 66 & 0 & 0 & 0 & 11 \\
\hline 22 & F, 79 & 2 & 0 & 0 & 12 \\
\hline
\end{tabular}

*Includes typical and atypical lymphocytes.

serum (IgMk) and urine ( $\kappa$ light chains) M bands were seen. The $M$ component of the serum was below $20 \mathrm{~g} / 1$ in all patients (table 1 ).

\section{CYTOLOGICAL FEATURES}

Lymphocytes with a distinct morphology were found in all the cases and constituted $38-99 \%$ of all the lymphoid cells present in the peripheral blood films. The characteristic cells were usually larger than the lymphocytes found in CLL (fig la), with diameters comparable with those of PLL prolymphocytes. The nuclei were round or ovoid, sometimes eccentric, with a clumped chromatin pattern, and in half the cases $40-90 \%$ of these lymphocytes showed a single prominent nucleolus, sometimes surrounded by heterochromatin, or associated with the nuclear membrane, or both, as is usually seen in prolymphocytes. The amount of cytoplasm was variable; in cells from most of the cases it was more abundant than that usually found in prolymphocytes, but in a few there was a predominance of lymphocytes with scanty cytoplasm.
A moderate degree of basophilia was always present. $\frac{0}{3}$ The most striking feature was a characteristic irregularity of the plasma membrane consisting of thin and $\delta$ short villi unevenly distributed and often concentrated in one pole of the cell. In lymphocytes with abundant cytoplasm, a few long, thin cytoplasmic $>$ projections were also seen in association with the membrane villi. In nearly every case there were N between 3 and $12 \%$ of plasmacytoid cells, which are characterised by a more pronounced cytoplasmic $\tilde{O}$ basophilia, and a clear perinuclear zone correspond- $N$ ing to the Golgi apparatus.

In nine of 10 cases tested a moderate to strongo staining for acid phosphatase was found in $10-30 \%$ of the villous lymphocytes, but the reaction was $\stackrel{\odot}{?}$ resistant to treatment with tartaric acid in only $4 \%$ of 0 the cells from two of these cases and, in the remainder, the lymphocytes did not react to tartrate resistant $\stackrel{\mathbb{}}{\Omega}$ acid phosphatase. Control slides of HCL samples $\mathbb{Q}$ stained in parallel for tartrate resistant acid phosphatase always reacted. 


\begin{tabular}{|c|c|c|c|c|}
\hline Platelets & White cells & Lymphoid cells* & \multirow{2}{*}{$\begin{array}{l}\text { Villous lymphocytes } \\
\text { (\% white cells) }\end{array}$} & \multirow[b]{2}{*}{ Paraprotein class $(\mathrm{g} / \mathrm{l})$} \\
\hline & \multicolumn{2}{|l|}{$\left(\times 10^{9} / 1\right)$} & & \\
\hline 116 & 11 & $9 \cdot 2$ & 82 & Not tested \\
\hline 205 & 16 & $11 \cdot 0$ & 50 & Not tested \\
\hline 71 & 15 & $14 \cdot 7$ & 84 & $\operatorname{IgM}$ (serum) (16.5) \\
\hline Not recorded & 13 & $6 \cdot 8$ & 34 & IgM (serum) (4·8) \\
\hline 99 & 13 & $10 \cdot 1$ & 72 & None \\
\hline 148 & 11 & $5 \cdot 8$ & 28 & $\kappa$ (urine) \\
\hline 120 & 20 & $18 \cdot 6$ & 80 & IgM (serum) $(4 \cdot 5) \kappa$ (urine) \\
\hline Not recorded & 20 & $17 \cdot 6$ & 55 & Not tested \\
\hline 199 & 23 & $18 \cdot 4$ & 59 & Not tested \\
\hline 217 & 11 & $8 \cdot 5$ & 29 & $\kappa$ (urine) \\
\hline 200 & 38 & $35 \cdot 3$ & 72 & IgM (serum) (19.4) \\
\hline 129 & 11 & $7 \cdot 7$ & 39 & None \\
\hline 125 & 4 & $2 \cdot 0$ & 28 & IgM (serum) (2.0) \\
\hline 156 & 32 & $28 \cdot 8$ & 66 & Not tested \\
\hline 83 & 7 & $5 \cdot 6$ & 46 & None \\
\hline 110 & 3 & 1.9 & 39 & None \\
\hline 120 & 20 & $13 \cdot 8$ & 41 & None \\
\hline 57 & 30 & $28 \cdot 2$ & 90 & IgG (serum) (6.0) \\
\hline 153 & 15 & $9 \cdot 5$ & 34 & IgG (serum) (7.6) \\
\hline 180 & 30 & $26 \cdot 1$ & 79 & None \\
\hline 129 & 23 & $22 \cdot 5$ & 55 & Not tested \\
\hline 150 & 20 & $12 \cdot 8$ & 64 & Not tested \\
\hline
\end{tabular}

Cell volume studies were done in 10 cases, and showed that the median volume of the lymphoid cells was $355.8(67.4)$ fl. This was slightly, though not significantly, larger than the median volume of peripheral blood cells from 22 patients with PLL, but was significantly smaller $(p<0.01)$ than the median volume of hairy cells from 11 patients with $\mathrm{HCL}$ (table 2).

\section{IMMUNOLOGICAL MARKERS}

All the neoplastic cells showed B cell markers (table 3 ). The number of $\mathrm{T}$ lymphocytes in these samples was low, E rosettes mean $20.3(10.9) \%$ and was similar to that found in HCL, E rosettes mean 20.3 $(12.8) \%$, although significantly higher than in CLL and PLL, E rosettes are $8.3(7.0) \%$ and $4.6(3.4) \%$, respectively.

Most cells in each sample expressed SmIg of moderate to strong intensity, with light chain restricted to the $\kappa$ isotype in 14 cases and to $\lambda$ in eight. We tested for heavy chains in 15 cases: the commonest phenotype found was IgMD in six patients, followed by
IgM in two, and IgG in two. The combinations IgMA, IgMDA, IgDA and IgDG were present in one case each. In cells from one patient no heavy chain was found.

Only three samples were tested for the expression of CyIg: this was negative in two, but in the third sample $80 \%$ of the lymphocytes showed brightly stained granules of intracytoplasmic IgG $\lambda$.

Usually less than $30 \%$ of cells formed $M$ rosettes, similar to the pattern seen in PLL and HCL (table 2). Most of the villous lymphocytes reacted with the monoclonal antibody anti-class II MHC antigens (GRB1), anti-B1, FMC7 and RFB1. Reactions with the latter antibody were always weak, in contrast to the strong pattern of staining with RFB1 shown by HCL cells. Significant reactivity with OKT10 was found in only two of nine cases tested, whereas all four samples tested reacted to BU 11. The lymphocytes from most of the patients did not express the Tac and the B2 antigens, and reactions to the monoclonal antibody anti-HC2 were usually negative. Expression of the p67 antigen was usually low; the 


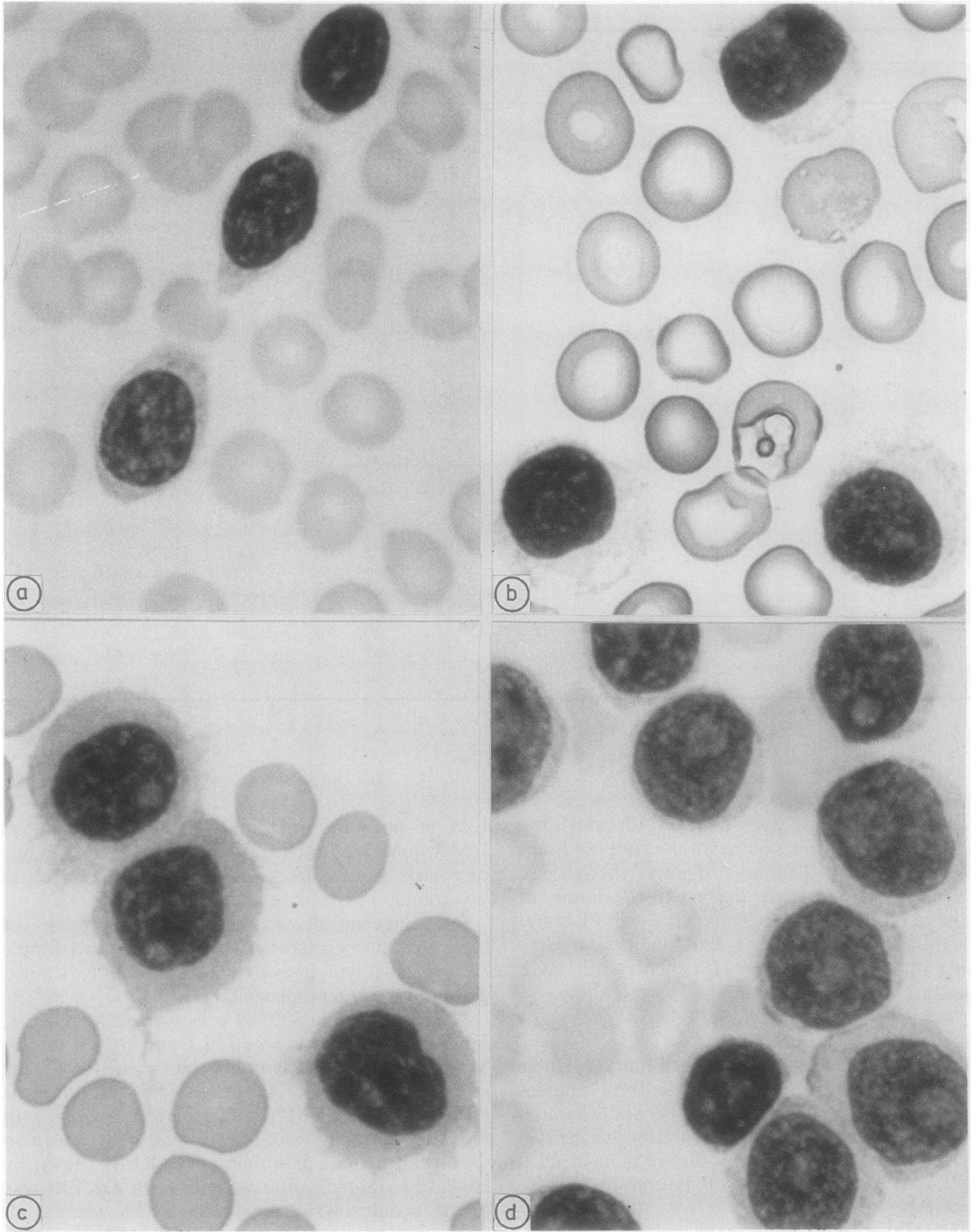

Fig 1 Light microscopy of peripheral blood cells in: (a) SLVL; (b) HCL; (c) HCL variant; (d) PLL. (May-Grünwald Giemsa). 
Table 2 Clinical and laboratory features of B cell lymphoproliferative disorders

\begin{tabular}{|c|c|c|c|c|c|}
\hline & $C L L$ & $P L L$ & $S L V L$ & $H C L V$ & $H C L$ \\
\hline Male:female ratio & $22: 1$ & $1 \cdot 6: 1$ & 1.9:1 & $4 \cdot 0: 1$ & $4 \cdot 2: 1$ \\
\hline Age (years) mean (SD) & $64 \cdot 2(9 \cdot 9)$ & $70 \cdot 0(8 \cdot 8)$ & $72 \cdot 2(9 \cdot 0)$ & $61 \cdot 1(14 \cdot 4)$ & $57 \cdot 6(14 \cdot 0)$ \\
\hline White cell count $\left(\times 10^{9} / 1\right)$ mean $(\mathrm{SD})$ & $112 \cdot 7(134)$ & $175 \cdot 8(143)$ & $17 \cdot 1(9 \cdot 2)$ & $87 \cdot 6(72 \cdot 5)$ & $13.0(5 \cdot 5)$ \\
\hline Spleen (cm below costal margin) mean (SD) & $4 \cdot 3(5 \cdot 9)$ & $10 \cdot 3(5 \cdot 8)$ & $10 \cdot 6(7 \cdot 7)$ & $10 \cdot 3(6 \cdot 5)$ & $\begin{array}{l}8 \cdot 4(6.0) \\
(\mathrm{n}=30)\end{array}$ \\
\hline Lymph node enlargement ( $\%$ cases) & 66 & 29 & 22 & $0^{*}$ & 6 \\
\hline$M$ band $\dagger$ ( $\%$ cases $)$ & (51) & (30) & 63 & 0 & (10) \\
\hline Median cell volume (fl) & $211 \cdot 5 \pm 32 \cdot 5$ & $307 \cdot 5 \pm 61 \cdot 8$ & $355.8 \pm 67.4$ & $433+$ & $526 \cdot 2 \pm 76 \cdot 4$ \\
\hline Tartrate resistant acid phosphatase & Negative & Negative & Negative & Negative & Positive \\
\hline Spleen infiltration & $\begin{array}{l}\text { White pulp (with } \\
\text { or without red } \\
\text { pulp) }\end{array}$ & $\begin{array}{l}\text { White pulp (with } \\
\text { or without red } \\
\text { pulp) }\end{array}$ & $\begin{array}{l}\text { White pulp (with } \\
\text { or without red } \\
\text { pulp) }\end{array}$ & Red pulp only & Red pulp only \\
\hline
\end{tabular}

*Information available for only three patients. $\nmid$ Numbers inside parentheses refer to published data. $\ddagger$ Measurement available for only one case.

higher percentage of CD5 positive cells (up to $44 \%$ ) in some cases corresponded to $\mathrm{T}$ lymphocytes, as assessed by $\mathrm{E}$ rosettes. A variable number of cells reacted with the monoclonal antibody $\mathrm{J} 5$ in the seven cases tested.

\section{HISTOLOGICAL EXAMINATION OF BONE}

\section{MARROW AND SPLEEN}

Aspiration of bone marrow was attempted in 17 cases and was unsuccessful in only three; in all the others a good specimen was obtained. In half of these the aspirates contained less than $30 \%$ of morphologically normal lymphocytes, and in the other half there was an infiltration of $37-90 \%$ lymphoid cells, a number of which had villous features. The histological examination of the core biopsy material showed a mixed, diffuse patchy lymphocytic infiltration in three, a moderate infiltration of nodular type in three (all with a normal aspirate), and absence of lymphomatous disease in two cases.

Histological examination of splenic tissue (figs 2 and 3) showed varying degrees of disease of both white and red pulps, with evidence of lymphoplasmacytic differentiation, in all six spleens examined. In three there was a preferential infiltration into white pulp (fig 2), whereas in the other three the lymphoid infiltration was seen predominantly in the red pulp (fig 3), although there was also white pulp disease. In all cases the cells had clumped nuclear chromatin, with a variable proportion of nucleolated forms, and tended to be arranged in nodules, which in two cases showed margination-that is, the presence of larger cells in the periphery of the nodules with the smaller cells in the centre (fig 4). The histological appearances of the spleens were therefore similar to those seen in CLL and immunocytomas. As well as the features described above, the cells were not arranged in the regular spaced manner that is charcteristically seen in HCL.

\section{Discussion}

The patients described as cases of SLVL in this study had some clinical and laboratory features that are also found in HCL, PLL, and CLL. When these are found in combination, however, they seem to consti-

Table 3 Immunological markers in splenic lymphoma with villous lymphocytes

\begin{tabular}{lccc}
\hline Marker & No tested & $\begin{array}{l}\text { Mean }(S D) \\
(\% \text { positive cells) }\end{array}$ & Range \\
\hline M rosettes & 19 & $20 \cdot 2(19 \cdot 8)$ & $0-55$ \\
GRB1 & 17 & $63 \cdot 3(21 \cdot 5)$ & $18-96$ \\
B1 (CD20) & 7 & $58 \cdot 6(27 \cdot 5)$ & $22-94$ \\
B2 (CD21) & 6 & $18 \cdot 7(34 \cdot 8)$ & $0-88^{*}$ \\
FMC7 & 16 & $69.9(15 \cdot 3)$ & $37-93$ \\
UCHT2 (CD5) & 15 & $22 \cdot 6(16 \cdot 9)$ & $2-63$ \\
RFB1 & 11 & $53 \cdot 5(24 \cdot 5)$ & $3-85$ \\
HC2 & 11 & $0.5(1 \cdot 8)$ & $0-6 \dagger$ \\
Tac (CD25) & 7 & $12 \cdot 7(21 \cdot 1)$ & $1-60 \ddagger$ \\
J5 (CD10) & 7 & $49 \cdot 1(25 \cdot 3)$ & $28-92$ \\
OKT10 & 9 & $10.6(14 \cdot 7)$ & $0-45$ \\
BU 11§ & 4 & $78 \cdot 3(20 \cdot 8)$ & $56-97$ \\
\hline
\end{tabular}

* One case $=88 \%$; one case $=20 \%$; all others $<2 \%$ positive cells. tOnly one case $=6 \%$ positive cells; all others negative. †Only one case $=60 \%$; all others $<10 \%$ positive cells. $\S$ Tested only on fixed cells by immunoperoxidase. 
Melo, Hegde, Parreira, Thompson, Lampert, Catovsky

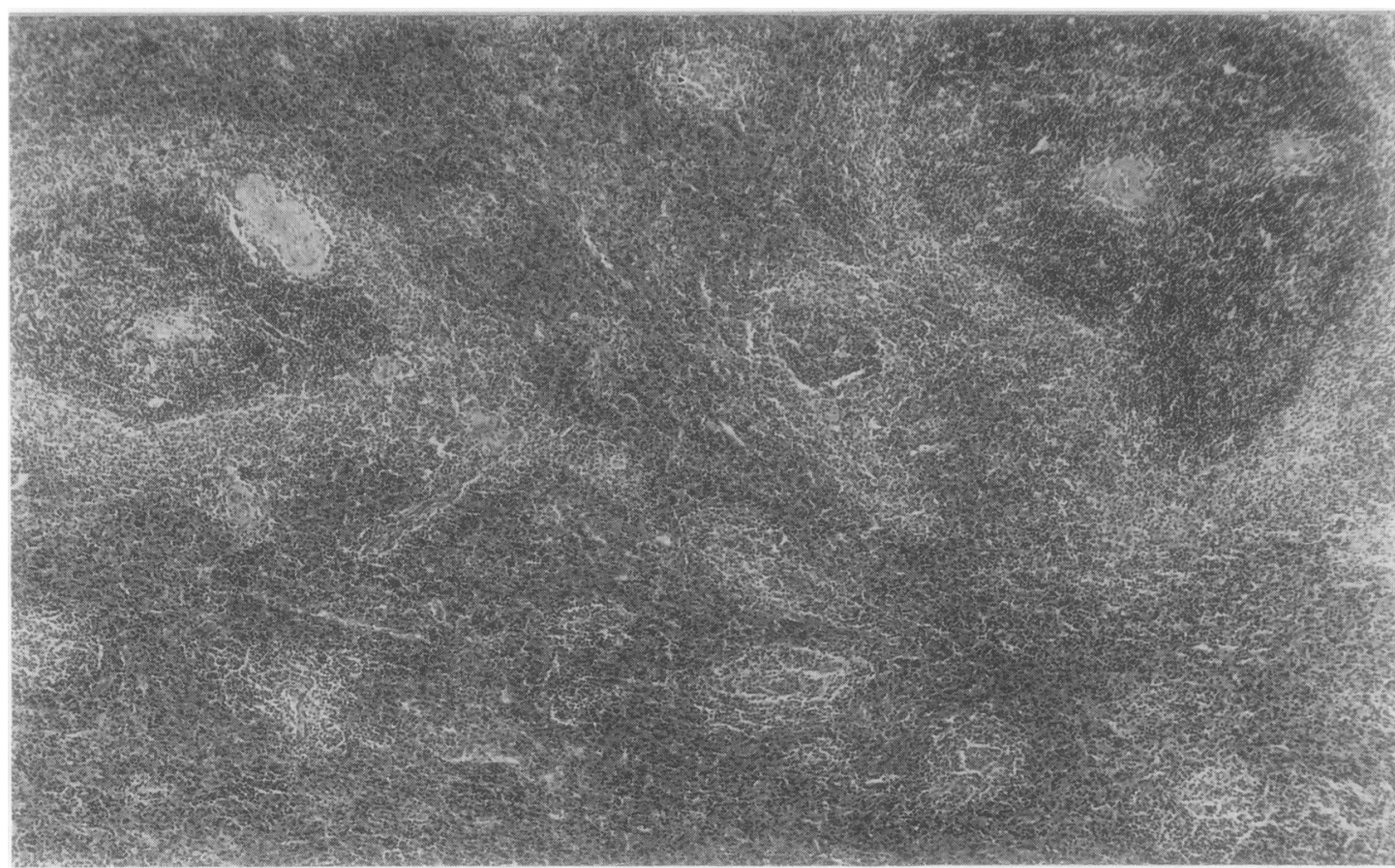

Fig 2 Histological slide of spleen showing enlarged, irregular, white pulp areas with strong margination seen as pale band around edge of white pulp.

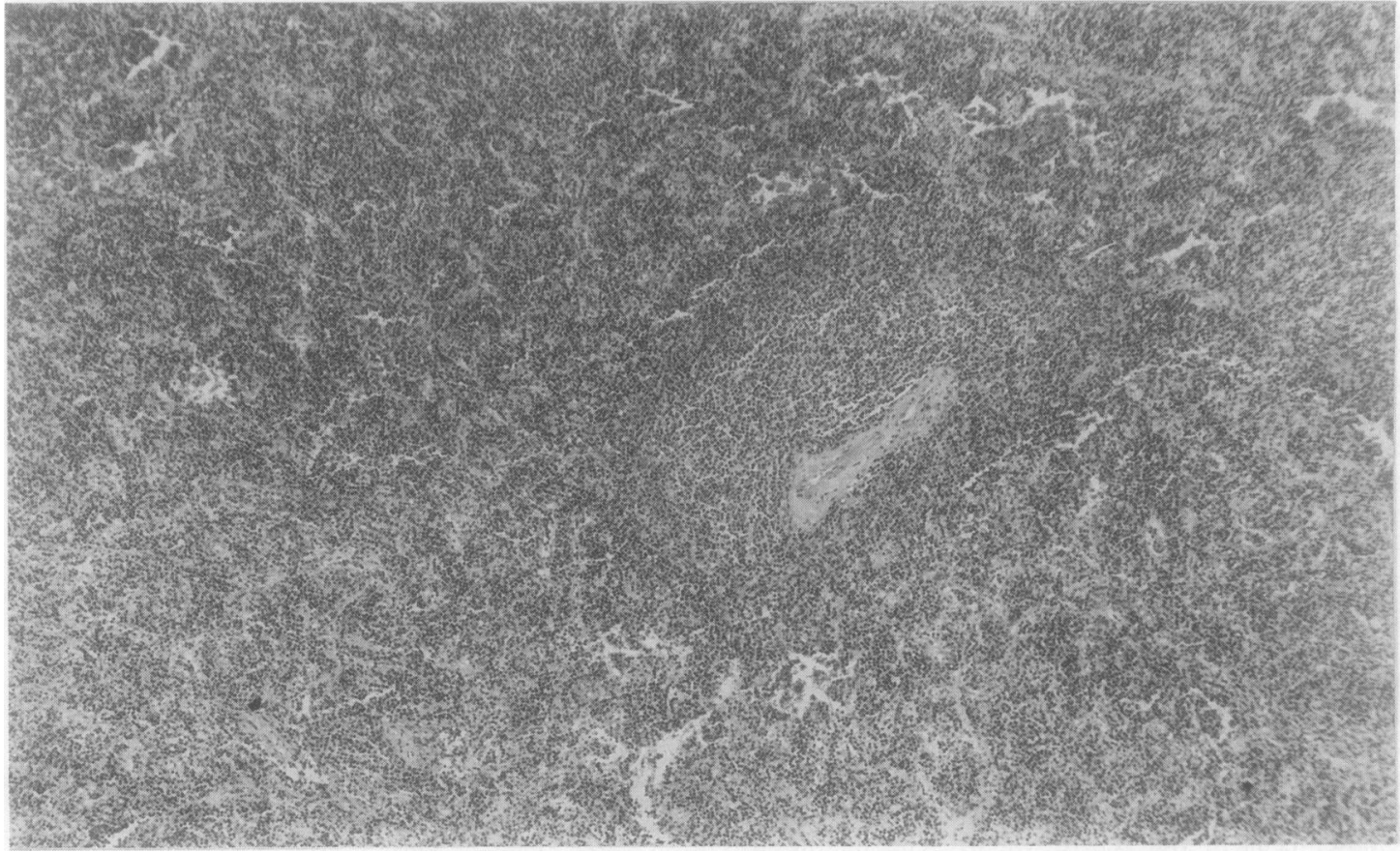

Fig 3 Spleen section showing diffuse infiltration of red pulp with less white pulp disease than that seen in fig 2. 


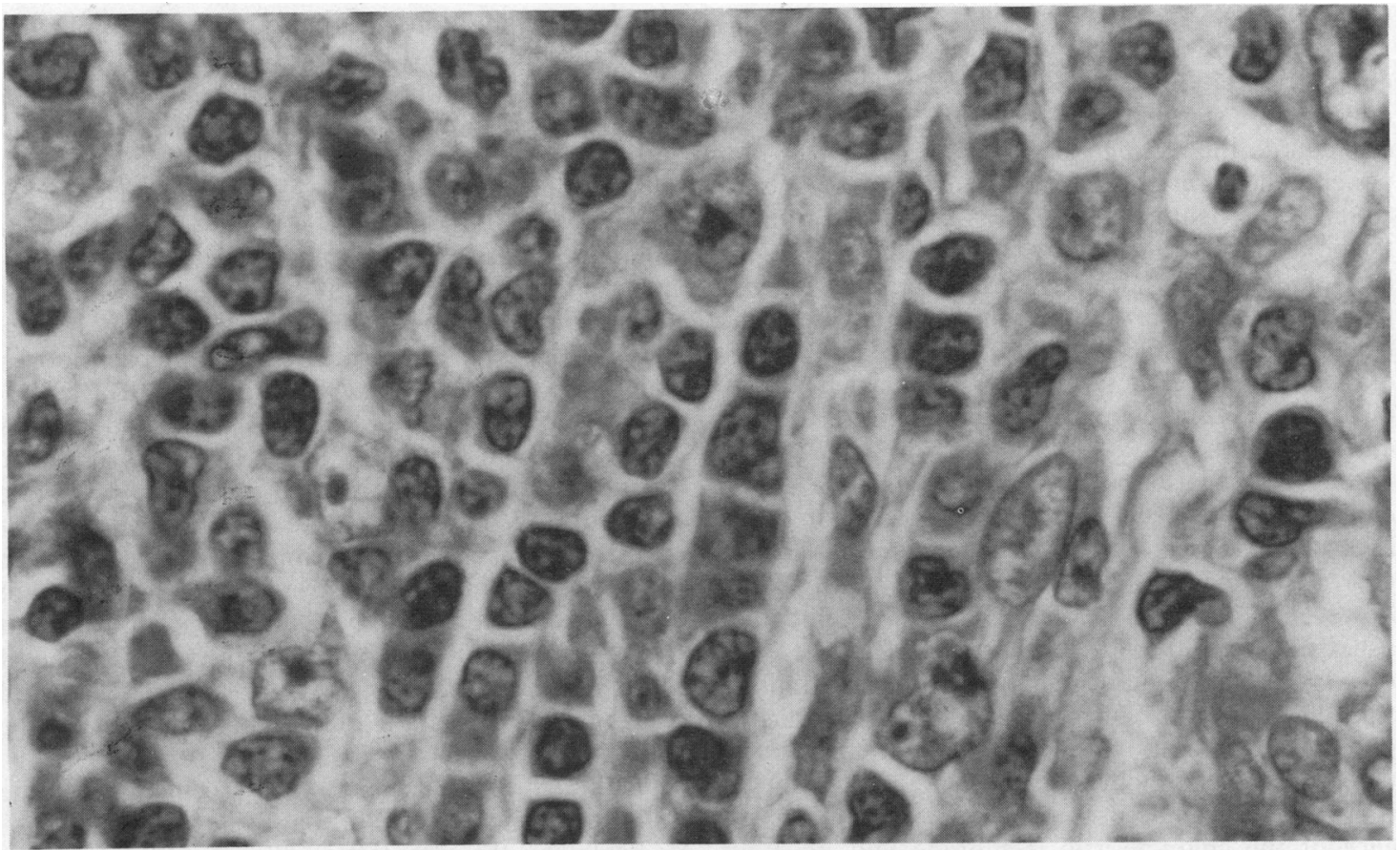

Fig 4 Lymphoid cells from splenic white pulp. Small cells show coarse clumped nuclear chromatin; occasional cells with large nuclei, dispersed chromatin, and large nucleoli are seen in marginal zone.

tute a disease which is distinct from chronic B lymphoid leukaemias. ${ }^{1-5}$

This type of lymphoma predominantly affects men, with a male:female ratio of $1.8: 1$ in our series, which is similar to that reported by Fohlmeister et $a l^{3}$ and Spriano et $a l^{5}$; Neiman et $a l^{2}{ }^{2}$ however, reported a higher incidence in women (male:female ratio 1:4). The patients are usually between 60 and 70 years old and present with a few mild symptoms, most often caused by an enlarged spleen. The enlargement is usually considerable ${ }^{5}$, although in $18 \%$ of the patients from our series the spleen was not palpable at diagnosis. Lymph node disease is minimal or absent. Moderately severe anaemia and thrombocytopenia are seen in about half the cases, and the white cell count is usually raised, although it rarely exceeds $25 \times$ $10^{9} / 1$. The neoplastic cells in the peripheral blood are medium sized lymphocytes with characteristic morphology, the hallmark of which is the presence of irregularly distributed short membrane villi. Monoclonal gammaglobulinaemia, usually IgM and below $20 \mathrm{~g} / \mathrm{l}$, may be found in over $50 \%$ of the cases.

Immunologically the villous lymphocytes are mature B cells, as shown by their strong SmIg expression, low $M$ rosette formation, and reactivity with the monoclonal antibodies GRB1, anti-B1(CD20),
FMC7 and BU11. In some cases a further degree of maturation may be seen in some of the cells which are shown to express CyIg and the T10 antigen.

The differential diagnosis of SLVL from other B cell leukaemias with obvious splenic enlargement must be made initially on the basis of the peripheral blood morphology (fig 1). The villous lymphocytes may initially be mistaken for HCL cells because of their irregular membrane outline (fig 1a); a careful examination, however, will disclose the different pattern of villi distribution, as well as the nuclear characteristics of chromatin and nucleolus which are distinct from those of hairy cells (fig $1 \mathrm{~b}$ ). Villous lymphocytes are also different from the hairy cells of HCL variant (fig 1c) where the nucleus is centrally located and usually shows a prominent nucleolus, the cytoplasm is abundant, and membrane hairy projections are homogeneously distributed-as in typical hairy cells-which contrasts with the preferential polar localisation of short and thin villi, or of the few, long, broad based projections characteristic of SLVL lymphocytes. In some cases the distinction between the three types of cells may not be immediately apparent by light microscopical examination alone, and electron microscopic studies (unpublished observations) or cell volume measurements, or both, may be needed 
(table 2).

In addition to morphological features, SLVL differs from HCL in the lack of tartrate resistant acid phosphatase staining on its cells; the increased white cell count; the peripheral blood plasmacytic component; the significantly higher incidence of monoclonal gammopathy; the less extensive infiltration of the bone marrow in the early stages of the disease; the lack of the spaced arrangement of the tumour lymphocytes; and the constant lymphomatous role of the white pulp of the spleen. In addition, the lymphocytes of SLVL do not express the two HCL markers recognised by the monoclonal antibodies anti-HC2 and anti-Tac (table 4).

SLVL may also be distinguished from PLL on clinical grounds. The two diseases are similar in sex and age incidence, as well as in preferential splenic enlargement with little or no lymphadenopathy. PLL, however, is characterised by a high white cell count, usually above $100 \times 10^{9} / 1$, whereas none of the cases of SLVL from our series or from other reports showed leucocytosis of more than $40 \times 10^{9} / 1$. Morphologically, villous lymphocytes may be erroneously taken for prolymphocytes (fig ld) if a large proportion display a single prominent nucleolus. The presence of the characteristic membrane villi, together with the cytoplasmic basophilia, is usually enough to identify these cells as being distinct from prolymphocytes. Membrane markers are not helpful for the differential diagnosis, except in the lack of reactivity of PLL cells with the monoclonal antibody BU 11, but this needs to be confirmed on a larger number of samples (table 4).

In some cases of SLVL the circulating cells are relatively small, with scanty cytoplasm and inconspicuous nucleoli. These cases are usually confused with a pure splenic form of CLL. The distinction should be made if membrane villi are present in these lymphocytes by both light and electron microscopic exam-

ination. In addition, the pattern of immunological markers in the two diseases is quite distinct (table 4).

Some of the features of SLVL overlap with those of Waldenstrom's macroglobulinaemia, in which the cells show a more pronounced plasmacytic differentiation, with higher concentrations of IgM band $(>20 \mathrm{~g} / \mathrm{l})$ than in SLVL, and disease in the bone marrow is more pronounced. Cases of Waldenstrom's macroglobulinaemia rarely have high white cell counts, and villous lymphocytes have not been described as a characteristic feature. One patient originally selected for this study had $30 \%$ of PB lymphocytes resembling those of SLVL. His clinical features (an IgM peak of $61 \mathrm{~g} / \mathrm{l}$, hyperviscosity symptoms, pronounced bone marrow infiltration, and low white cell count), however, showed that he had Waldenstrom's macroglobulinaemia. The B cells of both conditions are probably arrested at similar stages of maturation, but there may be differences that account for their predominance in the spleen in SLVL. The M band in some patients with SLVL is of IgG class, and only urinary excretion of free light chains can be found in others.

Although SLVL seems to be a specific disease, the villous lymphocytes are probably closely related biologically to the neoplastic cells of other types of chronic B lymphoid leukaemia. Thus SLVL cells, hairy cells of both typical HCL and HCL variant, and prolymphocytes share most of the immunological markers of B lymphocytes at an intermediate to late stage of maturation (table 4). In addition, the spleen seems to have a key role in all four disorders, either as a site of genesis or of preferential homing of the neoplastic cells. The histological extent of the role of the spleen is, however, different in these diseases, with predominantly white pulp infiltration in CLL, PLL, and SLVL, though in some cases of PLL and SLVL the red pulp may also be affected, and in HCL and HCL variant there is an exclusive and massive red

Table 4 Membrane marker studies in B lymphoproliferative disorders

\begin{tabular}{|c|c|c|c|c|c|}
\hline & $C L L$ & $P L L$ & $\begin{array}{c}S L V L \\
(\% \text { positive cells) }\end{array}$ & $H C L V$ & $H C L$ \\
\hline $\mathbf{M}$ rosettes & $>70$ & $<30$ & $<30$ & $<30$ & $<30$ \\
\hline CD 5 & $>70$ & $30-70$ & $<30$ & 0 & 0 \\
\hline FMC7 & $<30$ & $>70$ & $>70$ & $>70$ & $>70$ \\
\hline RFB 1 & $30-70$ & $<30$ & $30-70$ & $>70$ & $>70$ \\
\hline Anti-HC2 & 0 & 0 & $\mathbf{0}$ & 0 & $30-70$ \\
\hline Anti-Tac & Few & Few & Few & 0 & $>70$ \\
\hline OKT10 & 0 & 0 & Few & 0 & 0 \\
\hline BU 11 & 0 & 0 & $>70$ & $>70$ & $>70$ \\
\hline SmIg type intensity & $\begin{array}{l}\text { MD } \\
\text { Weak }\end{array}$ & $\begin{array}{l}\text { MD } \\
\text { Strong }\end{array}$ & $\begin{array}{l}\text { MD(AG) } \\
\text { Moderate }\end{array}$ & Goderate & $\begin{array}{l}\text { MDAG } \\
\text { Moderate }\end{array}$ \\
\hline
\end{tabular}


pulp infiltration with white pulp atrophy. Waldenstrom's macroglobulinaemia and SLVL are probably part of the same histological class known as immunocytomas. ${ }^{12}$ The importance of the different histological patterns in the pathogenesis of each disease is not yet known.

The trend towards a more objective classification and characterisation of distinct diseases in the group of lymphoproliferative disorders results from the need to find the best treatment for patients with different types of malignancies. The separation of SLVL from HCL, the disease with which it is most often confused, will permit more accurate analyses of results of treatment and prognosis. Although the follow up for most patients in our series was too short for analysis of survival, we observed that SLVL usually has a benign clinical course and no treatment is required in some patients for long periods. Patients who are symptomatic benefit from splenectomy (six in this series), splenic irradiation, or low doses of chlorambucil, as used in CLL. We have no experience of treating this disease with $\alpha$ interferon, which is active against HCL, but which is apparently ineffective in HCL variant and PLL (D Catovsky, unpublished observation).

We thank J Behrens, $H$ Cohen, J Hayes, AV Hoffbrand, C Lee, V Oxley, IR Samaratunga, ML Tillyer, EN Trounson, S Varadi, DK Watson and Y Williams for referring patients and providing blood samples, and A Karabyn, R Morilla, V Moss and JE Rylah for performing some of the marker studies. JVM was supported by a grant from CAPES (Brazil).

\section{References}

1 Theml H, Burger A, Keiditsch E, et al. Klinisch Beobachtungen zur Charakterisierung des splenomegalen Immunozytoms. Med Klin Wochenshr 1977;72:1019-32.

2 Neiman RS, Sullivan AL, Jaffe R. Malignant lymphoma simulating leukemic reticuloendotheliosis. A clinicopathologic study of ten cases. Cancer 1979;43:329-42.

3 Fohlmeister I, Schaefer HE, Modder B, Hellriegel K-P, Fischer R. Chronische lymphoproliferative Erkrankung unter dem Bild einer Haarzell-Leukamie. Blut 1981;42:367-77.

4 Palutke M, Tabaczka P, Mirchandani I, Goldfarb S. Lymphocytic lymphoma simulating hairy cell leukemia: a consideration of reliable and unreliable diagnostic features. Cancer 1981; 48:2047-55.

5 Spriano P, Barosi G, Invernizzi R, et al. Splenomegalic immunocytoma with circulating hairy cells. Report of eight cases and revision of the literature. Haematologica 1986;71:25-33.

6 Catovsky D, O'Brien M, Melo JV, Wardle J, Brosovic M. Hairy cell leukemia (HCL) variant: an intermediate disease between HCL and B-prolymphocytic leukemia. Semin Oncol 1984; 11:362-9.

7 Shibata A, Bennett JM, Castoldi GL, et al. Recommended methods for cytological procedures in haematology. Clin Lab Haematol 1985;7:55-74.

8 Costello C, Wardle J, Catovsky D, Lewis SM. Cell volume studies in B-cell leukaemia. Br J Haematol 1980;45:209-14.

9 Posnett DN, Chiorazzi N, Kunkel HG. Monoclonal antibodies with specificity for hairy cell leukemia cells. J Clin Invest 1982;70:254-61.

10 Melo JV, San Miguel JF, Moss VE, Catovsky D. The membrane phenotype of hairy cell leukemia: a study with monoclonal antibodies. Semin Oncol 1984;11:381-5.

11 Nathan PD, Walker L, Hardie D, et al. An antigenic study of human plasma cells in normal tissue and in myeloma: identification of a novel plasma cell associated antigen. Clin Exp Immunol 1986;65:12-9.

12 Lennert K. Malignant lymphomas other than Hodgkin's disease. Berlin: Springer-Verlag, 1978.

Requests for reprints to: Dr D Catovsky, MRC Leukaemia Unit, RPMS, Hammersmith Hospital, Ducane Road, London W12 0HS, England. 